\title{
Invertebrates, Land
}

National Cancer Institute

\section{Source}

National Cancer Institute. Invertebrates, Land. NCI Thesaurus. Code C14359.

Terrestrial animals without back bones 